\title{
Özel Hastane Finansal Performansının DuPont Finansal Analiz Yöntemiyle Değerlendirilmesi (Araştırma Makalesi)
}

Evaluation Financial Performance of Private Hospital by DuPont Financial Analysis Method

Doi: 10.29023/alanyaakademik.874789

Ferda IŞIKÇELİK

Arş.Gör., Ankara Üniversitesi, Sağllk Bilimleri Fakültesi, Sağllk Yönetimi Bölümü

ferdabuluc@gmail.com

Orcid No: 0000-0002-7975-4141

\section{Fatih DURUR}

Arş.Gör., Ankara Üniversitesi, Săgllk Bilimleri Fakültesi, Sağlık Yönetimi Bölümü durur@ankara.edu.tr

Orcid No: 0000-0001-9682-0019

\section{Meliha Meliş GÜNALTAY}

Arş.Gör., Ankara Üniversitesi, Să̆llk Bilimleri Fakültesi, Sağlık Yönetimi Bölümü mmgok@ankara.edu.tr

Orcid No: 0000-0002-2883-4416

Bu makaleye atıfta bulunmak için: Işıkçelik, F., Durur, F. \& Günaltay, M.M. (2021). "Özel Hastane Finansal Performansının DuPont Finansal Analiz Yöntemiyle Değerlendirilmesi”. Alanya Akademik Bakış, 5(2), Sayfa No.773-791.

\begin{tabular}{|c|c|}
\hline \multirow[b]{2}{*}{ Anahtar kelimeler: } & ÖZET \\
\hline & $\begin{array}{l}\text { Bu arasstırmada Borsa İstanbul'da işlem gören bir hastaneler grubunun } 2015 \text { - } \\
2019 \text { yıllarl arasındaki finansal performansl DuPont finansal analiz }\end{array}$ \\
\hline Aktif Karlılı̆̆l, & $\begin{array}{l}\text { tekniğiyle değerlendirilmiştir. Karlılı oranlarl Türkiye özel hastane } \\
\text { ortalama karlılı oranlartvla karsllastırılmıstır. Hastaneler grubunun }\end{array}$ \\
\hline $\begin{array}{l}\text { Finansal Performans, } \\
\text { Özsermaye Karlılığg }\end{array}$ & $\begin{array}{l}\text { karlılık oranlarının 2015-2018 yılları arasında negatif olduğu, özsermayenin } \\
\text { düşük, yabancı kaynak kullanımının yüksek, maliyet ve giderlerinin fazla, net } \\
\text { karın negatif olduğu ve zarar edildiği saptanmıştır. } 2019 \text { yılında ise karlılık }\end{array}$ \\
\hline Makale Geliş Tarihi: & oranları pozitif değerde olmakla birlikte özsermayenin düşük, yabancı kaynak \\
\hline 04.02 .2021 & kullanımının yüksek, maliyet ve giderlerinin fazla olduğu tespit edilmiştir. \\
\hline & Hastaneler grubunun DuPont karlılık oranları 2015-2018 yıllarında Türkiye \\
\hline 23.03.2021 & $\begin{array}{l}\text { ortalamasından düşük iken } 2019 \text { yılında ise yüksek olduğu saptanmıştır. Bu } \\
\text { bağlamda hastaneler grubuna yabancı kaynak kullanımının azaltılması ve } \\
\text { özsermaye kullanımının artırılması, maliyetler ve giderleri azaltıcı önlemler } \\
\text { alınması önerilmektedir. }\end{array}$ \\
\hline
\end{tabular}

Keywords:

Return on Assets, DuPont Analysis, Financial ABSTRACT

In this study, DuPont Financial Analysis Method is used to evaluate the financial performance of a group of hospitals traded on Borsa Istanbul from 2015 to 2019. Profitability ratios are compared with the average profitability 
ratio of Turkey's private hospitals. It is found that the profit rates of the hospital group are negative between 2015 and 2018, as well as a decrease in equity, high use of foreign resources, high costs and expenses, and the net profit is negatively affected. In 2019, it is determined that the profitability ratios are positive, however the equity is low, the use of foreign resources is high, and the costs and expenses are high. It is determined that DuPont profitability ratios of hospital group in 2015-2018 are below the average in Turkey, while they are above the average in 2019. In this context, it is recommended that the hospital group take measures to reduce the use of foreign resources, increase the use of equity, and reduce costs and expenses.

\section{GíRiş}

Finansal açıdan başarılı işletmeler, mevcut kaynaklarını istenilen düzeyde finanse edebilen hem borç hem de özsermaye ile dengeli fon sağlama yeteneğine sahip olan işletmelerdir (Özgülbaş vd., 2008). Bu başarının sağlanmasında finansal performansın ölçülmesi ve geliştirilmesi büyük önem taşımaktadır (Gruen ve Howarth, 2005). Finansal performansın ölçümünde yararlanılan finansal analizler, yatırım, finansman ve fiyat belirleme gibi işletmeyle ilgili kararların verilmesi, işletmenin hedeflerini gerçekleştirme ve verimlilik düzeyinin tespiti için kullanılmaktadır. Ayrıca bu analizler ile işletmenin mali durumu, karlılık durumu, mali yönden gelişmesinin yeterli olup olmadığı gibi konular incelenerek değerlendirilebilmektedir (Ağırbaş, 2014: 69). Bu sayede işletmeler kârı ve pazar değerini maksimize eden politikaları belirleyebilmektedir (Okka vd., 2015: 120).

Kendine has özellikleri nedeniyle diğer hizmet alanlarından ayrılan sağlık hizmetlerinde meydana gelen hızlı değişim, yaşlı nüfus oranının ve kronik hastalıkların artması gibi nedenlerle birleşerek sağlık kurumları üzerindeki finansal baskıyı artırmıştır (Bülüç vd., 2017). Sağlık hizmetlerinde yaşanan talep artışına rağmen hizmet sunumunda kıt kaynakların varlığ sağlık kurumlarının sayısal yönünü ön plana çıkarmaktadır (Turgut vd., 2019: 135). Sürekli değişen hasta taleplerine cevap verebilmek, piyasada kalıcı olmak ve sağlık hizmetlerinin sürekliliğini sağlamak için hem kamu hem de özel sektörde bulunan sağlık kurumlarında finansal performansın değerlendirilmesi zorunluluk haline gelmiştir (Aydemir, 2018). Sağlık kurumlarında finansal performansın değerlendirilmesinde çeşitli yöntemlerden yararlanılmaktadır. Literatür incelendiğinde oran analizi, trend analizi, TOPSİS ve Veri Zarflama Analizi gibi çeşitli yöntemlerin sıklıkla kullanıldığı görülmektedir (Ayanoğlu vd., 2010; Alper ve Biçer, 2017; Balc1, 2017).

$\mathrm{Bu}$ çalışmada Borsa İstanbul'da işlem gören bir hastaneler grubunun 2015-2019 yılları arasındaki finansal performansını değerlendirmek amaçlanmıştır. Sağlık kurumlarında finansal performans değerlendirmesinde DuPont analizinden yararlanılmaktadır (Sheela ve Karthikeyan, 2012; Loukopoulos ve Roupas, 2014; Prajapati ve Danta, 2015; Turner vd., 2015; Çalışkan, 2015; Karadeniz ve Koşan, 2017; Noh vd., 2018; Creixans-Tenas ve Núria ArimanySerrat 2018; Nurul vd., 2018; Erduru, 2018; Mali, 2020). Literatür incelendiğinde araştırma bulgularının ülke ortalamalarıyla karşılaştırıldığı bir çalışmaya ulaşılamamıştır. Bu araştırmada ise ilgili hastaneler grubuna ait yayımlanan tüm finansal veriler analiz edilmiş olup araştırma bulguları Türkiye özel hastane işletmeleri ortalama oranları ile kıyaslanarak değerlendirilmiştir. Bu noktada araştırmanın özgün olduğu düşünülmektedir. 
Bu çalışmada DuPont Finansal Analiz yöntemi kullanılarak ilgili hastaneler grubunun Net Kar Oranı (ROS), Aktif Karlılığı (ROA) ve Özsermaye Karlılığı (ROE) karlılık oranları hesaplanmış ve bu oranlar yıllara göre Türkiye'deki özel hastane işletmelerinin ortalama karlılık oranları ile karşılaştırılarak değerlendirilmiştir. Çalışmanın ilk bölümünde DuPont Analizi ile ilgili teorik bilgiye ve literatür taraması sonuçlarına yer verilmiştir. İkinci bölümde çalışmanın yöntemi hakkında bilgiler yer almaktadır. Üçüncü bölümde araştırma sonucunda elde edilen bulgular sunulmuştur. Çalışmanın dördüncü ve son bölümünde ise araştırma sonuçları ve bu sonuçlar doğrultusunda geliştirilen öneriler yer almaktadır.

\subsection{DuPont Analizi}

DuPont analizi, işletmelerde finansal performansı etkileyen faktörleri değerlendirmek için yaygın olarak kullanılan bir yöntemdir (Chang vd., 2014). İlk olarak 1918 yılında kullanılan DuPont analizi, işletmenin finansal tablolarında yer alan verilerden yararlanarak işletmenin ROE ve ROA'sını belirlemeye çalışmaktadır (Poyraz, 2008: 107; Almazari, 2012). Finansal analizde sıklıkla kullanılan oran analizi gibi yöntemlerde her durum için ayrı bir oran hesaplanarak bunlar birbirinden ayrı biçimde yorumlanmaktadır (Gümüş ve Çıbık, 2018). Buna karşılık DuPont analizi aynı anda birden çok ve birbirleriyle ilişkili oranların hesaplanıp incelenmesiyle işletmenin finansal durumuna genel bir bakış sağlamakta ve yöneticilerin çeşitli oranlar arasındaki ilişkileri anlamalarına yardımcı olmaktadır (Gapenski, 2008). Bu yöntem işletmenin tümü için başvurulabilecek bir sistem olduğu gibi sadece işletmenin bir departmanı için de uygulanabilmektedir (Poyraz, 2008: 107).

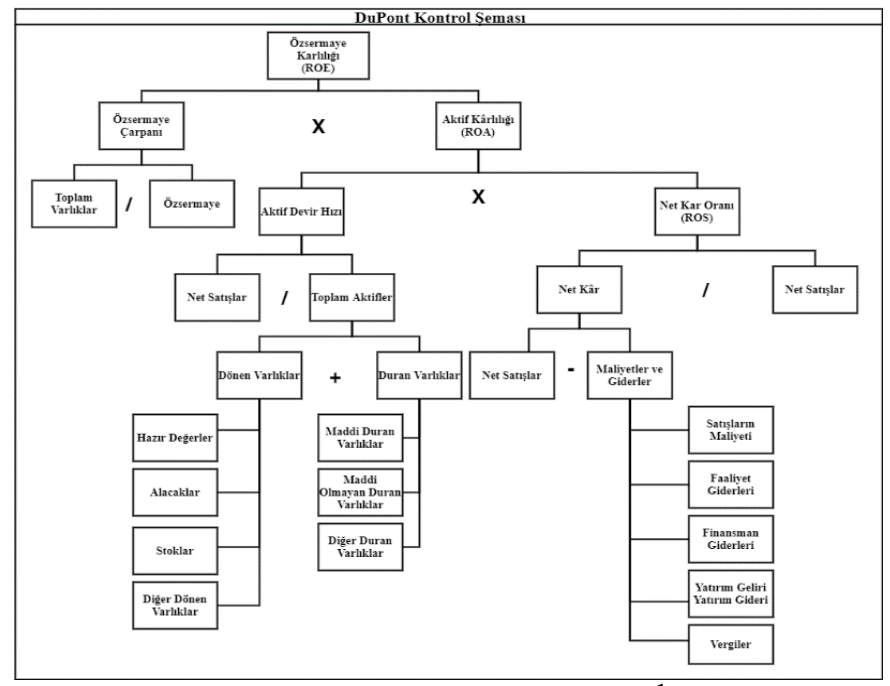

Şekil 1. DuPont Kontrol Şeması ${ }^{1}$

Kaynak: Gitman, 2002: 72; Akgüç, 2013: 84

Özay ve Taşel (2020: 796) meta analiz çalışmaları kapsamında inceledikleri araştırmalarda finansal performans göstergesi olarak en yaygın kullanılan göstergelerin sırasıyla ROA, ROS

\footnotetext{
${ }^{1}$ Şemada Alacaklar hesabı Ticari Alacaklar ve Diğer Alacaklar; Diğer Dönen Varlıklar hesabı Finansal Yatırımlar, Türev Araçlar, Peşin Ödenmiş Giderler ve Diğer Dönen Varlıklar; Diğer Duran Varlıklar hesabı Ticari Alacaklar, Diğer Alacaklar, Kullanım Hakkı Varlıkları, Peşin Ödenmiş Giderler, Ertelenmiş Vergi Varlığı ve Diğer Duran Varlıklar hesap kalemlerinden oluşmaktadır.
} 
ve ROE olduğunu saptamışlardır. DuPont analizi de işletmelerin finansal olarak yatırım performansını değerlendiren iki temel ölçüt olan ROA ve ROE ile yan ölçüt olarak kabul edilen ROE üzerine kurulmaktadır (Karadeniz ve Koşan, 2017). Bu kapsamda hesaplanan oranlar ve bileşenlerinin yer aldığı DuPont Kontrol Şeması Şekil 1'de yer almaktadır. Şema, karlılık oranlarındaki değişimler ve bu değişime neden olan hesap kalemlerinin hızlı bir şekilde tespit edilmesine imkân tanımaktadır.

DuPont finansal analiz tekniğinde temel karlılık oranı olan ROE'dir. ROE'nin hesaplanabilmesi için öncelikle işletme aktiflerinin karlılık durumlarının ölçümünde kullanılan ROA hesaplanmaktadır. ROA'nın hesaplanmasında kullanılan formül aşağıda yer elmaktadır (Poyraz, 2008: 107):

$$
R O A=\frac{\text { Net Kar }}{\text { Aktif Toplamı }}=\frac{\text { Net Kar }}{\text { Net Satışlar }} \times \frac{\text { Net Satışlar }}{\text { Aktif Toplamı }}
$$

ROA, aktif devir hızı ve ROS'un çarpılması ile bulunmaktadır (Akyüz vd., 2020). Bu oranın düşük olması varlık düzeyinin gereğinden fazla olduğunu ya da elde edilen kârın yetersiz olduğunu göstermektedir (Bakır ve Şahin, 2009). ROA'nın yükseltilmesi için ise ROS'ta ya da aktif devir hızında artışına neden olacak değişimlerin gerçekleştirilmesi gerekmektedir (Akgüç, 2013). Bu değişimlerin hangi hesap kalemlerinde olması gerektiği Şekil 1'de görsel olarak sunulmuştur.

ROE’nin hesaplanabilmesi için ikinci aşamada Özsermaye çarpanının hesaplanması gerekmektedir. Özsermaye çarpanı aktif toplamın özsermayeye bölünmesi ile bulunmaktadır (Chang vd., 2014). Özsermaye çarpanının düşük olması yatırım ya da borç durumları için risk oranının da düşük olduğunu göstermektedir (Akyüz vd., 2020). Özsermaye çarpanının yüksek olması ise yabancı kaynak kullanımının yüksek olduğu, dolayısıyla yatırım veya borç için yüksek risk bulunduğunu ifade etmektedir.

$$
\text { Özsermaye Çarpanı }=\frac{\text { Aktif Toplamı }}{\text { Özsermaye }}
$$

$\mathrm{Bu}$ oranların belirlenmesinin ardından ROE, Özsermaye çarpanı ve ROA'nın çarpılması ile elde edilir. ROE işletmenin varlık yönetimi, borç yönetimi ve karlılık oranları arasındaki ilişkiyi göstermektedir (Brigham ve Houston, 2014).

$$
R O E=\frac{\text { Net } K \text { âr }}{\text { Net Satışlar }} \times \frac{\text { Net Satıșlar }}{\text { Aktif Toplamı }} \times \frac{\text { Aktif Toplam }}{\text { Özsermaye }}
$$

DuPont analizi ile ilgili verilen bilgiler ışığında aktiflerin kullanım etkinliğinin düşük olmasının ROE'yi düşüreceği görülmektedir. Bu durumda işletme daha fazla borçlanarak başka bir ifadeyle finansal kaldıraçtan daha fazla yararlanarak ROE'yi artırabilecektir. Bu durumda işletmenin daha fazla borçlanarak ROE'yi artırabilmesi için aktif karlılığının borç maliyetinden yüksek olması gerekmektedir (Aydın vd., 2010).

\subsection{Literatür Taraması}

İşletmelerin finansal performanslarının değerlendirmesinde DuPont finansal analiz yöntemi önemli bir yere sahiptir. Literatür incelendiğinde tarım, turizm, enerji, otomotiv, yiyecek ve içecek sektörleri gibi birçok alanda yöntemin kullanıldığı görülmektedir (Baştürk, 2014; Ardıç, 2019; Hao ve Choi, 2019; Shahnia ve Endri, 2020; Büyükarıkan ve Eryılmaz, 2020; Akyüz 
2020). Aşağıda DuPont analizi ile sağlık sektörü dışındaki alanlarda yapılmış çalışma örneklerine yer verilmiştir.

Baştürk (2004), 1997-2001 yılları arasında Türkiye'deki sigorta işletmelerinin finansal performansını DuPont analizi ile değerlendirmiştir. Çalışma sonucunda hayat sigortası hizmeti veren işletmelerin net kâr marjı yüksek iken, hayat sigortası dışında hizmet veren işletmelerin aktif karlılığ 1 açısından daha düşük olduğunu saptamıştır.

Ardıç (2019) Çay İşletmeleri Kurumu'nun (ÇAYKUR) 2015, 2016 ve 2017 yıllarına ait finansal performansı ölçek temelinde DuPont analiz tekniği ile incelemiştir. Çalışma sonucunda aktif devir hızı, ROS, ROA ve ROE gibi değerlerle ölçülen finansal performansın 2015 yılında kısmen başarılı olduğu, 2016 ve özellikle 2017 yılında ise önceki yıllara oranla ciddi bir şekilde azaldığı belirlenmiştir.

Hao ve Choi (2019) Çin'de 7 çevrimiçi alışveriş şirketinin operasyonel performansını etki eden faktörlerin belirlemek için DuPont analizinden yararlanmışlardır. Çalışma sonucunda karma ürün satan işletmelerin tek bir özel ürün satan işletmelere göre daha yüksek varlık cirosuna sahip olduğu ancak daha düşük kar marjı elde ettikleri belirlenmiştir. Ayrıca çevrimiçi satışla beraber çevrim dışı satış da yapan işletmelerin kar marjı ve ROA'sının yalnız çevrimiçi satış yapan işletmelerden daha düşük olduğu tespit edilmiştir.

Akyüz ve diğerleri (2019) imalat alanında 2015-2017 yılları arasında faaliyet gösteren 9 farklı sektörün finansal performansları DuPont Analizi ile incelemiştir. Çalışma sonucunda Gıda, İçki ve Tütün sektöründe 2015-2016 yıllarında ROS değerlerinin düşük iken 2017 yılında yükselişe geçtiği belirlenmiştir. Sektörler aktif karlılık açısından incelendiğinde 2015 yılında eksi değer alırken, 2016-2017 yıllarında yükselişe geçtiği saptanmıştır. Bu nedenle 2016-2017 yılları arasında sektördeki işletmelerin varlıklarını daha verimli kullandıkları belirlenmiştir.

Armutlu ve Güngör (2019) Borsa İstanbul'da işlem gören turizm şirketlerinin 2011-2018 yılları arasında finansal performansları DuPont Analizi ile incelenmişlerdir. Çalışma sonucunda Türkiye'de 2016 yaşanan siyasi olayların turizm firmalarının net kâr marjı, aktif kârlılığı, öz kaynak kârlılı̆̆ı göstergelerini olumsuz yönde etkilediği belirlenmiştir.

Ladvenicova ve diğerleri (2019) V4 ülkelerinde (Slovakya, Çek Cumhuriyeti, Macaristan ve Polonya) tarım sektöründe faaliyet gösteren işletmelerinin 2009-2017 yılları arasında finansal performansları DuPont analizi ile incelemişlerdir. Çalışma sonucunda Çek Cumhuriyeti ve Slovakya'da tarım arazisinin ve sektörde çalışan sayısının azalması nedeni ile 2009-2017 yılları arasında ROE değerlerinin azaldığı tespit edilmiştir. Polonya ve Macaristan'da ise sektöre ilgi artmıştır bu nedenle ROE değerlerinde artış belirlenmiştir.

Mortaş (2020) Borsa İstanbul'da enerji sektöründe Elektrik Endeskinde (XELKT) işlem gören 7 şirketin 2016-2018 yılları arasında finansal performansları DuPont Analizi ile incelemiştir. Çalışma sonucunda 2016 yılında Enerjisa Enerji A.Ş. haricinde işletmelerin aktif karlılğı negatif sonuç verdiği, 2017 yılında karlılıkların 5 işletmenin yükselişe geçtiği, 2018 yılında ise toparlanmanın devam etmeyerek 4 işletmenin negatif sonuçlandığı belirlenmiştir.

Shahnia ve Endri (2020) Endonezya borsasında işlem gören ticaret, hizmet ve yatırım sektöründen 7 işletmenin finansal performanslarını DuPont analizi yöntemi ile incelemişlerdir. Çalışmada 2014-2018 yılları arasındaki veriler incelenmiş ve işletmeler içerisinde 3 tanesine yatırım yapmanın diğerlerine göre daha yüksek getiri sağlayacağı belirlenmiştir. 
Büyükarıkan ve Eryılmaz (2020) Borsa İstanbul'da işlem gören 4 tarım işletmesinin 2012 ve 2013 yıllarındaki finansal performansını DuPont analizi yöntemi ile incelemişılerdir. Çalışma sonucunda net kâr marjının düşük oluşunun yatırım kârlılığı yüzdesini de olumsuz etkilediği tespit edilmiştir.

Akyüz ve diğerleri (2020) Borsa İstanbul'da işlem gören 7 kâğıt ve kâğıt ürünleri işletmelerinin 2012-2018 yılları arasında öz kaynak verimlilikleri DuPont analizi yöntemi ile incelemişlerdir. Çalışma sonucunda yüksek satış hacminin ve düşük maliyetin işletmeler arasında başarı sıralamasında etkili olduğu belirlenmiştir. Ayrıca başarılı olan işletmelerin, net kar ve öz kaynak performanslarının da olumlu etki yarattığ tespit edilmiştir.

DuPont analizi farklı piyasa katılımcılarının gelecekteki kazançlar özsermaye getirileri gibi değerli bilgiler elde etmek için finansal tabloları kullanmasına olanak tanımaktadır. Diğer finansal performans ölçüm yöntemlerine göre avantajlarına rağmen sağlık alanında yapılmış çalışmalar sınırlı sayıdadır (Chang vd., 2011). Aşağıda sağlık sektöründe DuPont analizi ile finansal performans değerlendirmesi yapılan araştırmalara yer verilmiştir.

Sheela ve Karthikeyan (2012), 2003-2012 y1lları arasında Hindistan'da faaliyet gösteren Cipla, Ranbaxy ve Dr. Reddy Laboratuvarı isimli ilaç firmalarının finansal performansını DuPont analizi ile değerlendirilmiştir. Analiz neticesinde Cipla şirketi ROE'si ortalama 23.10, Ranbaxy şirketinin ROE'si ortalama 17.52 ve Dr. Reddy şirketinin ROE'si ortalama 17.00 olarak hesaplanmıştır.

Loukopoulos ve Roupas (2014), 2002-2012 yılları arasında Yunanistan'da bir sağlık grubu olan Hygeia'nın finansal performansını DuPont analizi ile değerlendirmişlerdir. Analiz neticesinde finansal kaldıracın 2012 yılında toplam hissedar zararlarının \%65'ini oluşturduğunu saptamışlardır. Ancak genel bir perspektiften bakıldığında, Hygeia'nın kısa vadeli likidite ve karlılık açısından kademeli bir toparlanma aşamasına girmiş olduğunu belirtmişlerdir. Ayrıca likidite yönetimine özel önem verilmesi gerektiğini ve Hygeia sektör ortalamalarına yakın nakit oranları göstermesine rağmen ağır bir borç yükü taşıdığını ifade etmişlerdir.

Prajapati ve Danta (2015), 2005-2014 yılları arasında Hindistan borsasında faaliyet gösteren Sun Pharmaceuticals, Dr. Reddy's Laboratories, Cipla ve Lupin ilaç şirketlerinin finansal performansları DuPont analizi ile değerlendirmişlerdir. Analiz neticesinde Sun Pharmaceuticals şirketinin özsermayesindeki artış nedeniyle özsermaye çarpanının azalması ve bu nedenle ROE'nin azaldığı sonucuna varılmıştır. Dr. Reddy’s Laboratories şirketi 2005-2007 yılları arasında hızlı bir büyüme göstermiştir ancak 2008 yılında yaşanan durgunluk nedeni ile kâr marjında büyük bir düşüş yaşamış olup ROE 24.2'den 9.7'ye gerilemiştir. Lupin şirketi kâr ve satışlarda düşüş yaşamamasına rağmen 2010 yılında özsermaye çarpanında ve ROE'de düşüş yaşanmıştır. Cipla şirketinin diğer şirketlere kıyasla ROE'sinin düşük olduğu, yıllar içerisinde düşüşün düzenli bir şekilde gerçekleştiği belirlenmiştir. Bütün şirketler değerlendirildiğinde yaşanan durgunluk sonrasında şirketlerin finansal performanslarının iyileştiği tespit edilmiştir.

Turner ve diğerleri (2015), 2007-2012 yılları arasında ABD'de faaliyet gösteren 3,255 hastanenin finansal performansını DuPont analizi ile değerlendirmişlerdir. Araştırma sonucunda özel hastanelerin kar marjlarının ve kaldıraç oranlarının daha yüksek olduğunu bunun yanı sıra daha verimli olduklarını saptamışlardır. Kamuya ait hastanelerin ise özsermaye 
karlılığı ve kâr marjlarının yüksek olmasına karşın düşük kaldıraç oranlarına sahip oldukları belirlemişlerdir.

Çalışkan (2015), 2009-2013 yılları arasında Türkiye'de faaliyet gösteren bir kamu hastanesinin finansal performansı DuPont analizi ile değerlendirmiştir. Analiz neticesinde 2009, 2011 ve 2012 yıllarında hastane karlılıklarının, 2010 ve 2013 yıllarına kıyasla daha yüksek olduğu belirlenmiştir. Hastanenin 2010 ve 2013 yıllarında yüksek maliyet ve düşük kâr elde ettiği sonucuna varılmıştır. $\mathrm{Bu}$ nedenle hastanenin 2009, 2011 ve 2012 yıllarında finansal performansının 2010 ve 2013 yıllarına kıyasla daha iyi olduğu belirlenmiştir.

Karadeniz ve Koşan (2017), 2012-2014 yılları arasında Türkiye Cumhuriyet Merkez Bankası (TCMB) tarafindan yayımlanan hastane hizmetleri sektörünün finansal verileri DuPont analizi ile değerlendirmişlerdir. Analiz neticesinde aktif ve özsermaye karlılıklarının 2012 ve 2014 yıllarında pozitif iken 2013 yılında negatif olduğu saptanmıştır. Sektörün yabancı kaynak kullanımlarının yüksek, bu nedenle aktif devir hızının düşük düzeyde ve dolayısıyla finansal riskin yüksek olduğu sonucuna varmışlardır.

Noh ve diğerleri (2018), 2016 yılında Kore'deki hastanelerin finansal performansını bakım kapsamına, kuruluş türüne, yerleşim yerine ve yatak sayısına göre değerlendirmişlerdir. Analiz neticesinde net kâr marjının özsermaye getirisi üzerinde en büyük etkiye sahip olduğunu belirlemişlerdir. Yatak sayısına göre, 160-299 yataklı genel hastanelerin; yerleşim yerine göre yerel belediyelerdeki hastanelerin en yüksek özsermaye getirisine sahip olduğunu saptamışlardır. Kuruluş türüne göre kamu hastanelerinin özel hastanelere kıyasla daha fazla yatırım yapmalarına rağmen düşük iş performansına sahip olduğunu sonucuna ulaşmışlardır.

Creixans-Tenas ve Núria Arimany-Serrat (2018), 2008-2015 yılları arasında İspanya'da hastanelerin finansal performansları DuPont Analizi ile değerlendirmişlerdir. Yapılan analiz neticesinde likidite ve borçluluk oranlarının hastanelerde finansal sağlığı önemli derecede etkilediğini bunun yanı sıra varlık yönetimini iyileştirebilmek için harcama yönetiminin iyi bir şekilde yapılması gerektiği sonucuna varılmıştır. Ayrıca çalışmada İspanya'daki hastanelerin finansal sürdürülebilirlikleri ve topluma uygun hizmet sunmaları için bu finansal göstergelerini kontrol etmesi gerektiği belirtilmiştir.

Nurul ve diğerleri (2018), 2011-2015 yılları arasında Bangladeş’te Beximco, Square, Renata, GlaxoSmithKline, Far Chemicals, Beacon, ACI, IBNSINA, ACI Formülasyonları ve Orion ilaç şirketlerinin finansal performansları DuPont analizi ile değerlendirmişlerdir. Analiz neticesinde Beacon ilaç şirketinin en düşük vergi ve faiz yüküne sahip olduğu, IBNSINA ilaç şirketinin en yüksek aktif devir hızına sahip olduğu, GlaxoSmithKline şirketinin kâr marjı, özsermaye ve kaldıraç oranı en yüksek ilaç şirketi olduğu belirlenmiştir. Araştırmanın sonucunda, GlaxoSmithKline diğer ilaç şirketlerine kıyasla en iyi finansal performansa sahip olduğu tespit edilmiştir.

Erduru (2018), 2015-2017 yılları arasında Türkiye'de ilaç sektörü alanında faaliyet gösteren ve hisse senetleri Borsa İstanbul'da faaliyet gösteren Nobel ilaç firması ve Selçuk Ecza Deposu'nun aktif ve özsermaye karlılığ 1 DuPont analizi ile değerlendirmiştir. Analiz sonucuna göre Nobel ilaç firmasının 2015-2017 yıllarına ilişkin yatırım karlılığının, Selçuk Ecza Deposu'nun yatırım karlılığından daha fazla olduğu buna karşılık Selçuk Ecza Deposu'nun ise aktiflerini Nobel İlaç Firması'na göre daha verimli kullandıkları tespit edilmiştir. 
Mali (2020) Hindistan'ın Gujarat eyaletinde faaliyet gösteren iki ilaç firmasının finansal performansını DuPont analizi yöntemi ile karşılaştırmıştır. Çalışmada firmaların 5 yıllık verileri incelenmiş, analiz sonucunda her iki firmanın da finansal performanslarında bir iyileşme olduğu ve karlılık performanslarında önemli bir farklılık bulunmadığı tespit edilmiştir.

Literatür incelemesi sonucunda sağlık sektörü veya diğer sektörlerde DuPont analizi yöntemiyle finansal performans ölçüldüğü ancak araştırma bulgularının ülke ortalamalarıyla karşılaştırılmadığ 1 görülmektedir. Bu araştırmada ise ilgili hastaneler grubuna ait yayımlanan tüm finansal veriler analiz edilmiş olup araştırma bulguları Türkiye özel hastane işletmeleri ortalama oranları ile kıyaslanarak değerlendirilmiştir. Bu aştırmanın literatürdeki bu eksikliği gidermesi noktasında özgün olduğu düşünülmektedir.

\section{YÖNTEM}

$\mathrm{Bu}$ çalışmada Borsa İstanbul'da işlem gören bir hastaneler grubunun finansal performansını değerlendirmek amaçlanmıştır. Bu kapsamda DuPont Finansal Analiz yöntemi kullanılarak ilgili hastaneler grubunun ROS, ROA ve ROE karlılık oranları hesaplanmış ve bu oranlar yıllara göre Türkiye'deki özel hastane işletmelerinin ortalama karlılık oranları ile karşılaştırılarak değerlendirilmiştir. Analiz kapsamında ilgili hastaneler grubuna bağlı hastane işletmelerinin 2015-2019 yıllarına ait konsolide bilanço ve gelir tablosu verilerinden yararlanılmıştır. Çalışma kapsamında 2015-2019 yıllarının seçilmesinin nedeni ilgili hastaneler grubuna ait bu yıllara ilişkin finansal tabloların yayımlanmış olmasıdır. Hastaneler grubuna ait finansal tablolar borsada işlem gören şirketlere ait kamuya açıklanması gereken bildirimlerin yayımlandığı Kamuyu Aydınlatma Platformu (KAP)'ndan; Türkiye özel hastane işletmelerine ait finansal tablolar ise TCMB'nin yayımladığı hastane hizmetleri alt sektörü istatistiklerinden yıllık veriler şeklinde elde edilmiştir. Hastaneler grubu bünyesinde Türkiye'nin çeşitli illerinde faaliyet gösteren hastane sayısı 2015 yılında 26, 2016 yılında 27, 2017 yılında 29, 2018 yılında 31 ve 2019 yılında 29'dur. Türkiye özel hastane işletmeleri alt sektöründe verisi yer alan hastane sayısı ise 2015 yılında 1,826, 2016 yılında 1,867, 2017 yılında 2,008, 2018 yılında 2,213 ve 2019 yılında 2,362'dir. Çalışmada kullanılan verilerinin kamuya açık ve erişilebilir olması nedeniyle etik kurul izni alınmamıştır.

\section{BULGULAR}

Çalışma kapsamındaki hastaneler grubuna bağlı hastanelerin 2015-2019 yıllarına ait konsolide finansal verileri ve DuPont analizi bulguları Tablo 1'de yer almaktadır. Hastaneler grubunun finansal verileri incelendiğinde özsermayenin yıllar itibariyle 104,670,000 TL ile 575,691,000 TL arasında dalgalanma gösterdiği, en düşük değerin 2017'de, en yüksek değerin 2018'de olduğu görülmektedir. Aktif toplam ve net satışlar 2015'ten 2019 yılına artmakta; varlıkların ve satışların arttığı görülmektedir. Dönem net karı veya zararı, grubun 2015-2018 yıllarında zarar ettiğini, en yüksek zararın 2017 yılında olduğunu ve 2019 yılında ise kar ettiğini göstermektedir. Aktif devir hızı yıllar itibariyle 0.82 ile 0.97 arasında dalgalanma göstermektedir. Özsermaye çarpanı yıllar itibariyle dalgalanma göstermekte ve en düşük değeri 2018 yılında iken en yüksek değeri 2017 yılındadır. Diğer bir deyişle yabancı kaynak kullanımının en az olduğu dönem 2018 iken en fazla olduğu yıl 2017 yılıdır. DuPont karlılık oranları 2015-2018 yıllarında negatif değerlere sahipken, 2019 yılında pozitif değerlere sahiptir. 
Tablo 1. Hastaneler Grubunun Finansal Verileri ve DuPont Analizi Bulgulari (2015-2019)

\begin{tabular}{|l|c|c|c|c|c|}
\hline & $\mathbf{2 0 1 5}$ & $\mathbf{2 0 1 6}$ & $\mathbf{2 0 1 7}$ & $\mathbf{2 0 1 8}$ & $\mathbf{2 0 1 9}$ \\
\hline Özsermaye (£) & $275,676,658$ & $265,239,000$ & $104,670,000$ & $575,691,000$ & $238,405,000$ \\
\hline Aktif Toplam (£) & $\begin{array}{c}2,256,316,91 \\
1\end{array}$ & $\begin{array}{c}2,435,303,00 \\
0\end{array}$ & $\begin{array}{c}2,721,336,00 \\
0\end{array}$ & $\begin{array}{c}3,238,877,00 \\
0\end{array}$ & $\begin{array}{c}3,914,486,00 \\
0\end{array}$ \\
\hline Net Satışlar (£) & $\begin{array}{c}1,843,386,41 \\
5\end{array}$ & $\begin{array}{c}2,160,072,00 \\
0\end{array}$ & $\begin{array}{c}2,576,076,00 \\
0\end{array}$ & $\begin{array}{c}3,131,559,00 \\
0\end{array}$ & $\begin{array}{c}3,703,598,00 \\
0\end{array}$ \\
\hline $\begin{array}{l}\text { Dönem Net Karı } \\
\text { veya Zararı (£) }\end{array}$ & $-64,921,787$ & $-48,709,000$ & $-132,782,000$ & $-103,680,000$ & $56,254,000$ \\
\hline Aktif Devir Hızı & 0.82 & 0.89 & 0.95 & 0.97 & 0.95 \\
\hline Özsermaye Çarpanı & 8.18 & 9.18 & 26.00 & 5.63 & 16.42 \\
\hline ROS & -0.04 & -0.02 & -0.05 & -0.03 & 0.02 \\
\hline ROA & -0.03 & -0.02 & -0.05 & -0.03 & 0.01 \\
\hline ROE & -0.24 & -0.18 & -1.27 & -0.18 & 0.24 \\
\hline
\end{tabular}

DuPont Kontrol Şeması, ROE'nin bileşenleri olan ROA ve Özsermaye çarpanı ile bunları oluşturan oranların ve finansal tablo kalemlerinin görsel sunumunu vermektedir. Böylece karlılık oranlarındaki değişimler ve hangi finansal tablo kalemlerinin buna neden olduğu detaylı bir şekilde sunulmaktadır. $\mathrm{Bu}$ araştırma kapsamında çizilen DuPont Kontrol Şemalarında hesap tutarları düşük olduğundan Alacaklar hesabı Ticari Alacaklar ve Diğer Alacaklar; Diğer Dönen Varlıklar hesabı Finansal Yatırımlar, Türev Araçlar, Peşin Ödenmiş Giderler ve Diğer Dönen Varlıklar; Diğer Duran Varlıklar hesabı Ticari Alacaklar, Diğer Alacaklar, Kullanım Hakkı Varlıkları, Peşin Ödenmiş Giderler, Ertelenmiş Vergi Varlığı ve Diğer Duran Varlıklar hesap kalemlerinden oluşmaktadır. 


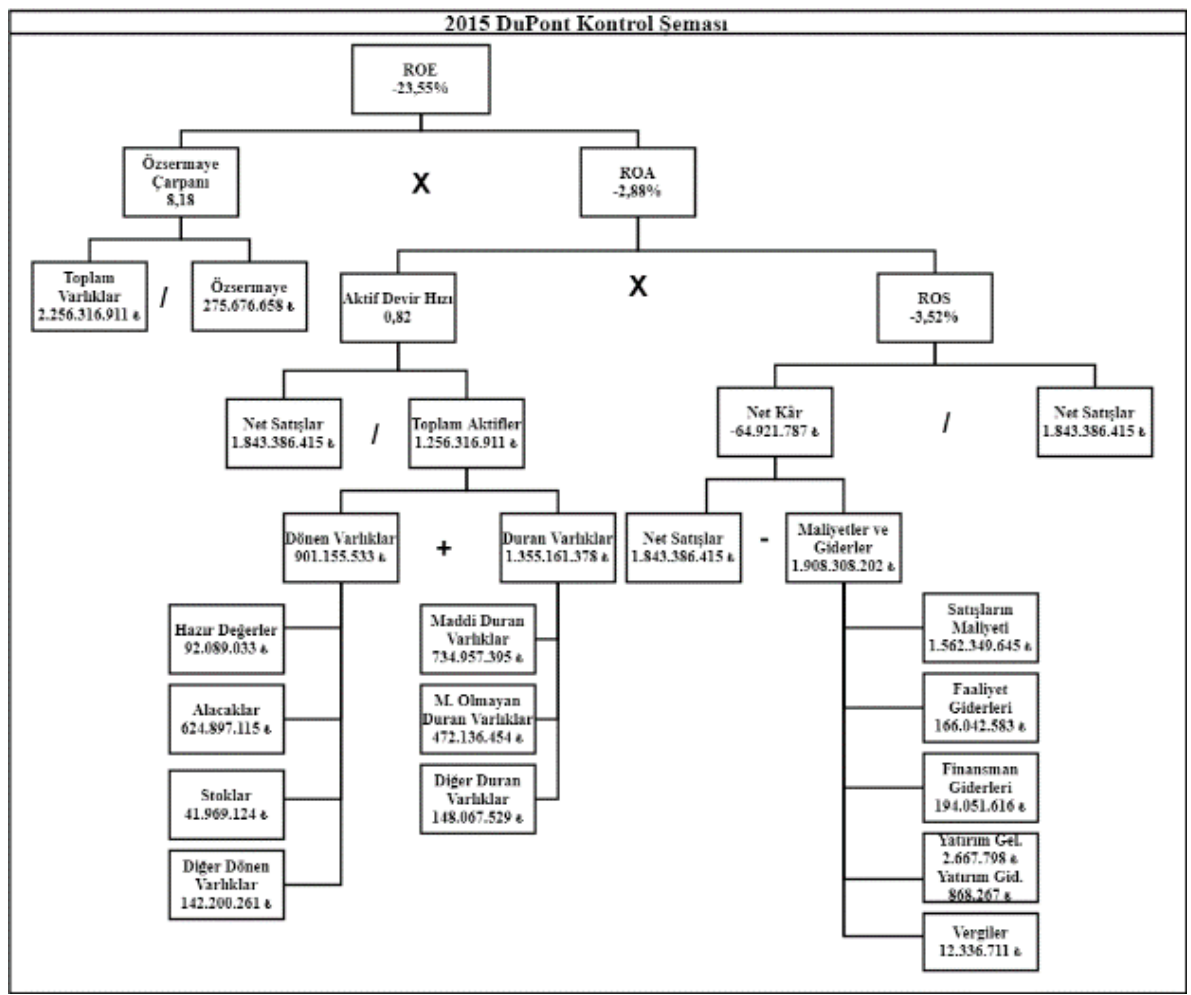

Şekil 2. 2015 Yılı DuPont Kontrol Şeması

Çalışma kapsamındaki hastaneler grubunun 2015 yılı DuPont Kontrol Şeması Şekil 2'de yer almaktadır. 2015 yılı DuPont Kontrol Şeması incelendiğinde, ROE \%-23.55; ROE’yi oluşturan ROA \%-2.88, Özsermaye çarpanı 8.18 'dir. Özsermaye çarpanı diğer bir deyişle finansal kaldıraç, varlıklar (2,256,316,911 TL) arasında Özsermaye (275,676,658 TL)'nin düşük olduğunu göstermektedir. ROE'nin negatif olması ROA'nın; ROA'nın negatif olması ise ROS (\%-3.52)'un negatif olmasından kaynaklanmaktadır. ROS, 1,843,386,415 TL satış karş1lığında $64,921,787$ TL zarar edildiğini göstermektedir. Net kar tutarının negatif olması maliyetler ve giderlerin net satışlardan yüksek olmasından kaynaklanmaktadır. Satışların maliyeti 1,562,349,645 TL ile maliyetler ve giderler arasında en yüksek paya sahip maliyet kalemidir. Aktif devir hızı, varlıkların hesap dönemi içinde $0.82 \mathrm{kez}$ devrettiğini göstermektedir. Aktif devir hızının bileşenlerine bakıldığında varlıkların çoğu duran varlıklardan; duran varlıkların çoğu maddi duran varlıklardan; dönen varlıkların çoğu alacaklardan oluşmaktadır. 


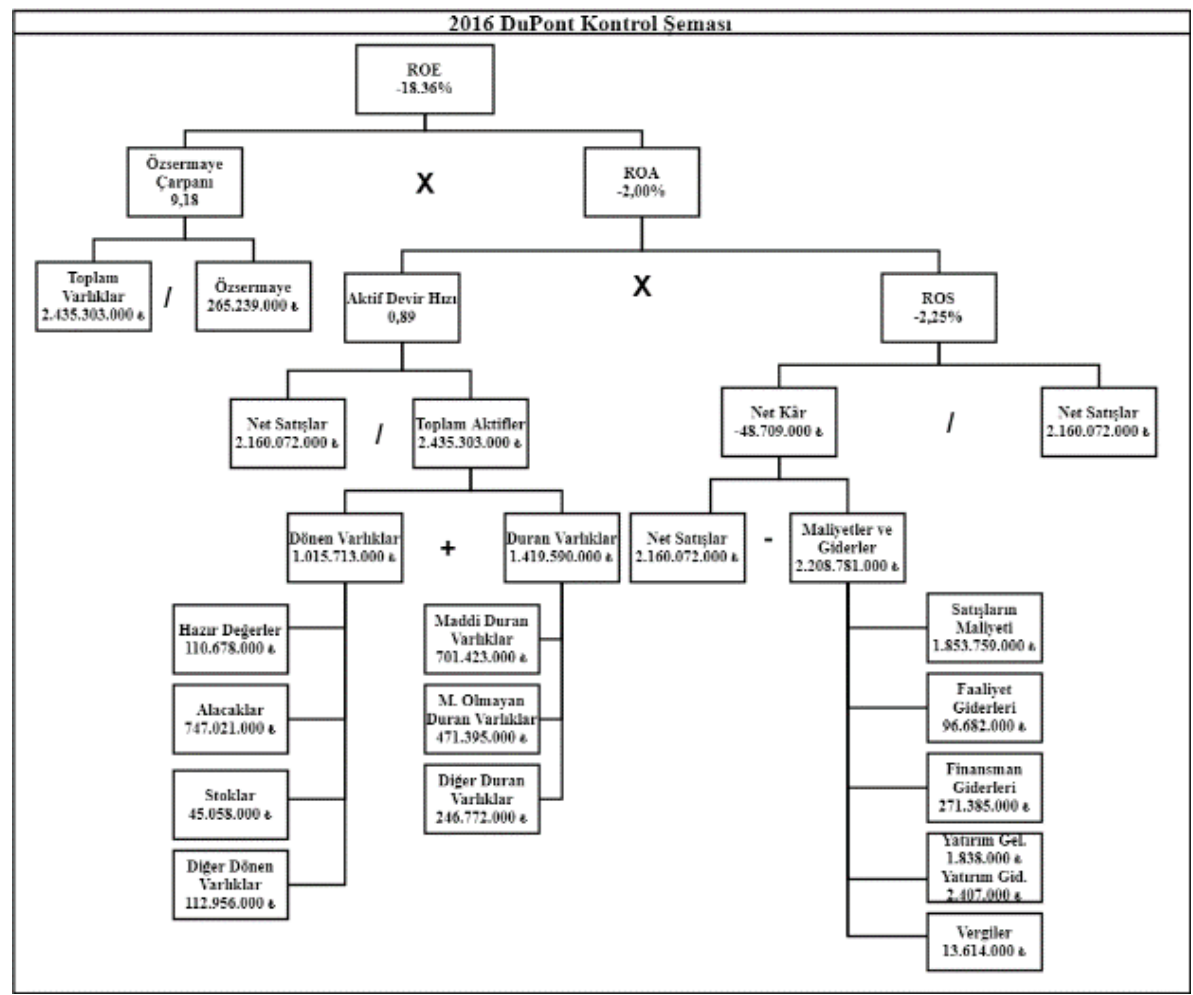

Şekil 3. 2016 Yılı DuPont Kontrol Şeması

Şekil 3'te yer alan 2016 yılı DuPont Kontrol Şemasına bakıldığında, ROE \%-18.36, ROA \%2.00 ve Özsermaye çarpanı $9.18^{\prime}$ dir. Özsermaye çarpanı, varlıklar (2,435,303,000 TL) arasında özsermayenin $(265,239,000 \mathrm{TL})$ düşük olduğunu ifade etmektedir. ROE'nin negatif olmas1 ROA'nın; ROA'nın negatif olması da ROS'un negatif olmasından kaynaklanmaktadır. ROS, 2,160,072,000 TL'lik net satış karşılığında 48,709,000 TL zarar edildiğini göstermektedir. Net kar hesabının negatif çıkması maliyet ve giderlerin net satışlardan yüksek olmasından kaynaklanmaktadır. Maliyetler ve giderlerin büyük çoğunluğu satışların maliyetinden oluşmaktadır. ROA'nın diğer bileşeni olan aktif devir hızı faaliyet dönemi içerisinde varlıkların $0.89 \mathrm{kez}$ devrettiğini ifade etmektedir. Varlıkların çoğu duran varlıklardan; duran varlıkların çoğu maddi duran varlıklardan; dönen varlıkların çoğu alacaklardan oluşmaktadır. 


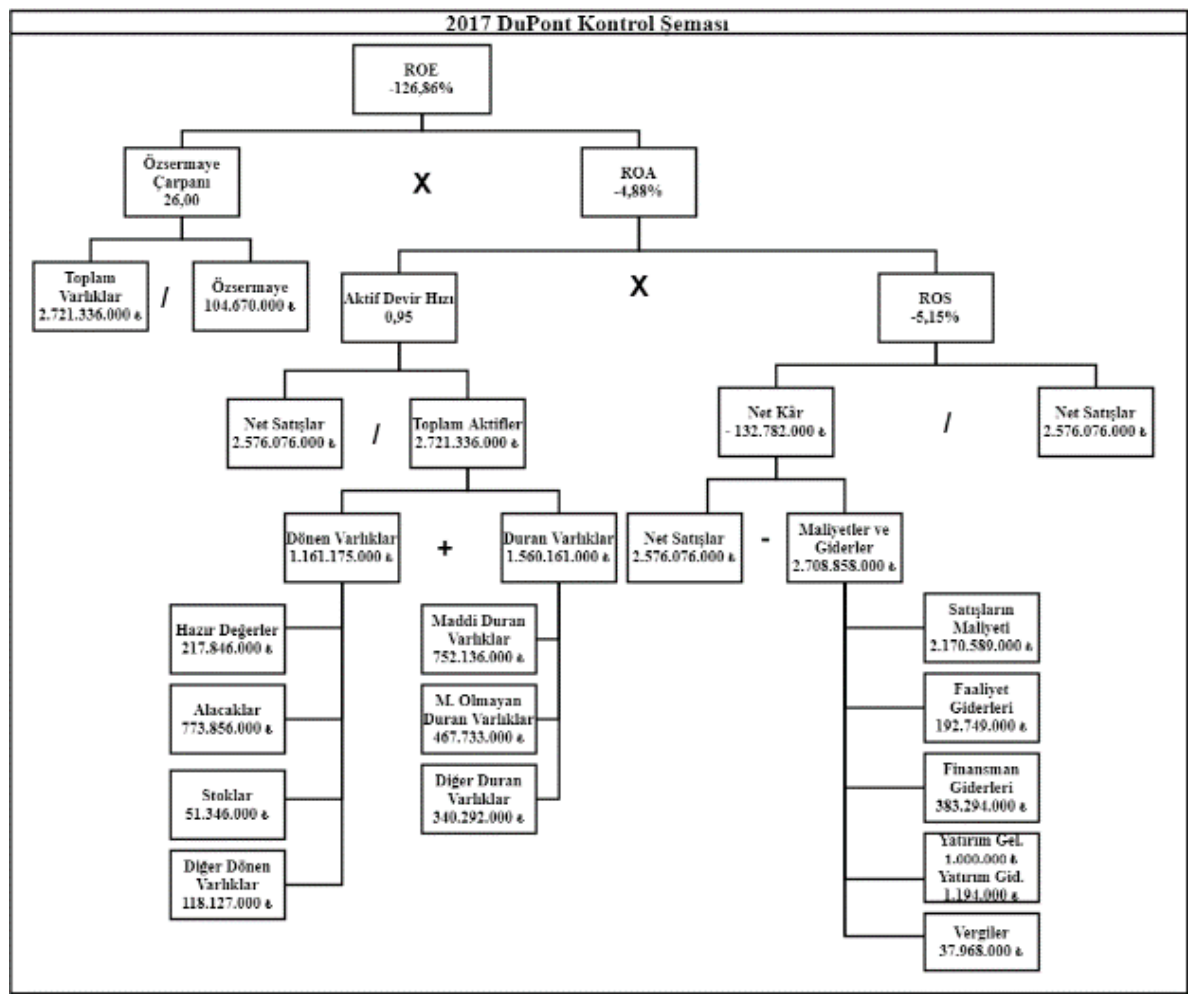

Şekil 4. 2017 Yılı DuPont Kontrol Şeması

2017 yılı Dupont Kontrol Şeması Şekil 4’te yer almaktadır. ROE \%-126.86, ROA \%-4.88 ve Özsermaye çarpanı 26.00'dır. Özsermaye çarpanı varlıklar (2,721,336,000 TL) içinde özsermayenin (104,670,000 TL) çok düşük olduğunu; yabancı kaynak kullanımının çok yüksek olduğunu göstermektedir. ROE'nin negatif olmasının nedeni ROA'nın; ROA'nın negatif olmasının nedeni ROS'un negatif olmasıdır. ROS, 2,576,076,000 TL net satış karşılığında $132,782,000$ TL zarar edildiğini göstermektedir. Diğer yıllara kıyasla net kar hesabının en düşük değere sahip olduğu yıldır. Net kar hesabının negatif değer almasının nedeni maliyetler ve giderlerin net satışlardan yüksek olmasıdır. Maliyet ve giderlerin yüksek olması ise satışların maliyetinin yüksek olmasından kaynaklanmaktadır. ROA'nın diğer bileşeni olan aktif devir hızı varlıkların hesap dönemi içinde 0.95 kez tekrar ettiğini ifade etmektedir. Aktif devir hızının bileşenleri incelendiğinde; varlıkların çoğunun duran varlıklardan; duran varlıkların çoğunun maddi duran varlıklardan, dönen varlıkların çoğunun alacaklardan oluştuğu görülmektedir. 


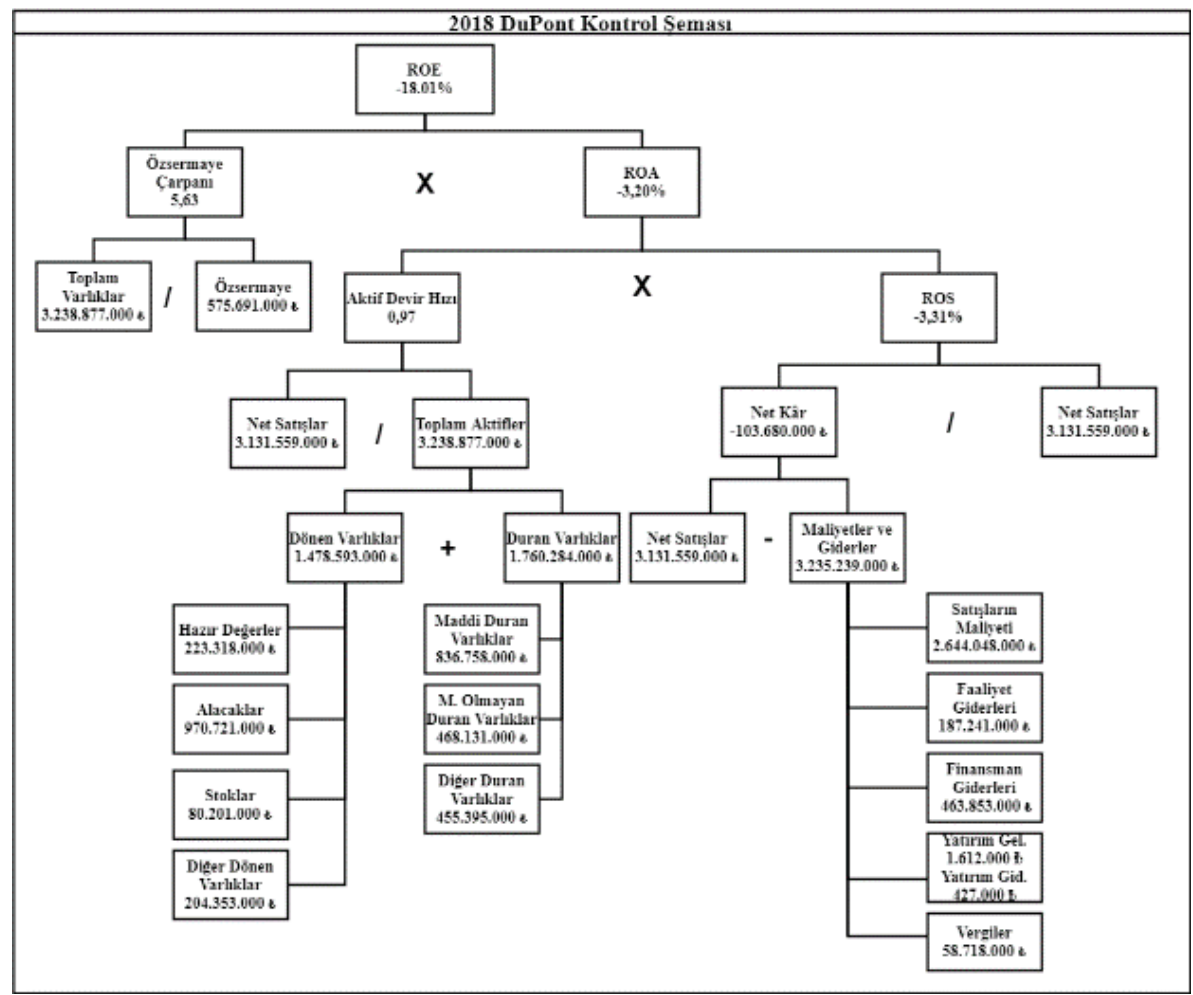

Şekil 5. 2018 Yılı DuPont Kontrol Şeması

2018 yılı DuPont Kontrol Şeması (Şekil 5) incelendiğinde, ROE \%-18.01, ROA \%-3.20 ve Özsermaye çarpanı 5.63'tür. Özsermaye çarpanı varlıklar $(3,238,877,000)$ içinde özsermaye (575,691,000 TL)'nin düşük olduğunu ifade etmektedir. Diğer bir deyişle yabancı kaynak kullanımı fazladır. ROE'nin negatif olmasının nedeni ROA'nın; ROA'nın negatif olmasının nedeni de ROS'un negatif olmasıdır. ROS, 3,131,559,000 TL net satış karşılığında 103,680,000 TL zarar edildiğini göstermektedir. Zarar edilmesinin nedeni maliyetler ve giderlerin net satışlardan yüksek olmasıdır. Maliyetler ve giderler arasında en yüksek değere sahip maliyet kalemi ise satışların maliyetidir. ROA'nın diğer bileşeni olan aktif devir hızı, hesap dönemi içerisinde varlıkların 0.97 kez devrettiğini ifade etmektedir. Diğer yıllara kıyasla aktif devir hızının en yüksek olduğu yani varlıkların verimliliğinin en yüksek olduğu yıldır. Aktif devir hızının bileşenlerinden oluşan aktif toplamının çoğunluğu duran varlıklardan, duran varlıkların çoğu maddi duran varlıklardan oluşmaktadır. Varlıkların diğer bileşeni olan dönen varlıkların çoğu alacaklardan meydana gelmektedir. 


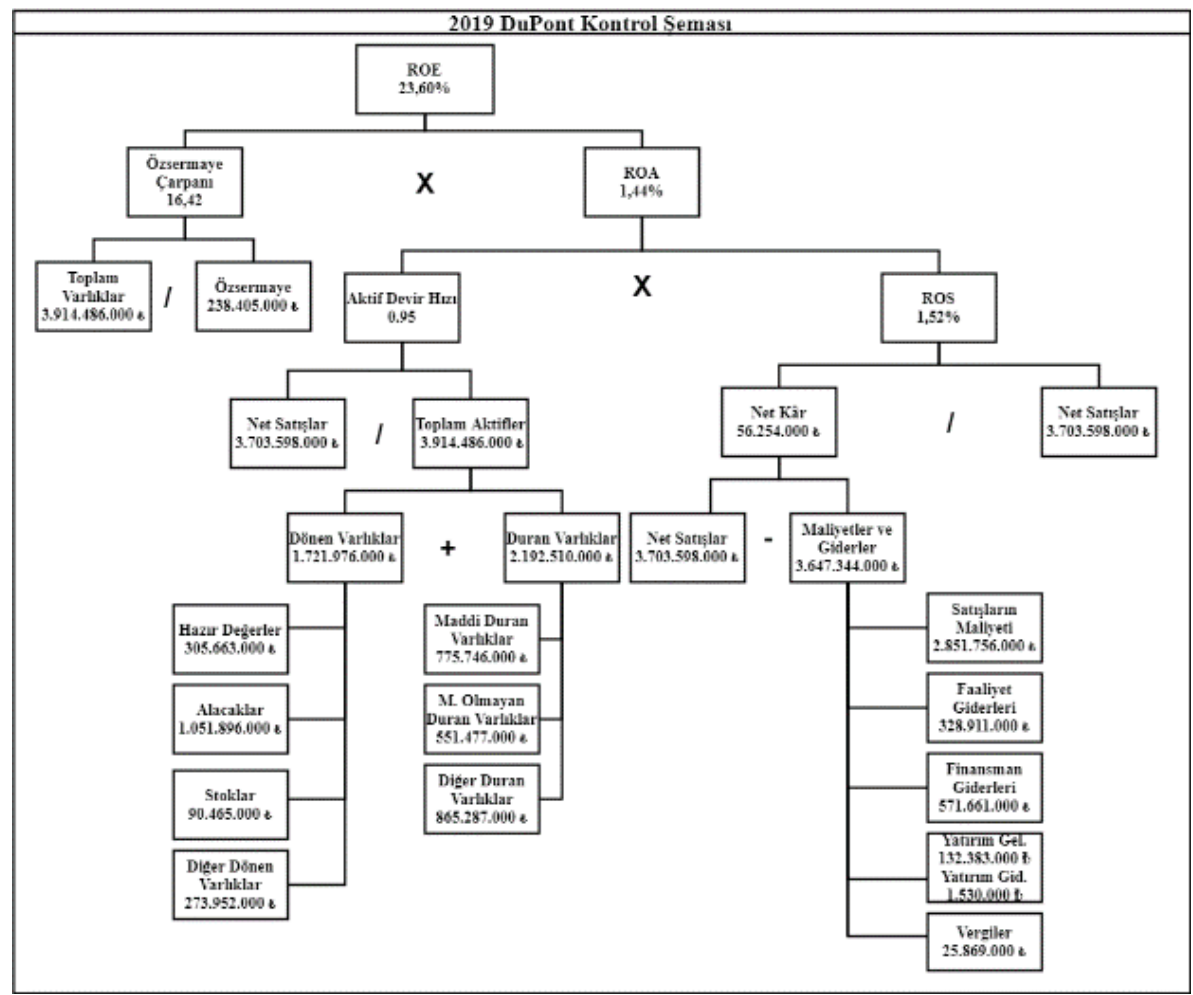

Şekil 6. 2019 Yılı DuPont Kontrol Şeması

2019 yılı DuPont Kontrol Şeması Şekil 6'de yer almaktadır. ROE \%23.60, ROA \%1.44 ve Özsermaye çarpanı 16.42'dir. Özsermaye çarpanı, varlıklar (3,914,486,000 TL) arasında özsermaye (238,405,000 TL)' nin düşük olduğunu belirtmektedir. ROS pozitif değerde ancak düşüktür. $\mathrm{Bu}$ durum net satışlara kıyasla net karın düşük olmasından kaynaklanmaktadır. Maliyetler ve giderler ile net satışlar arasındaki farkın düşük olması net karın düşük olmasının sebebidir. Maliyetler ve giderler arasındaki en yüksek maliyet kalemi ise satışların maliyetidir. ROA'nın diğer bileşeni olan aktif devir hızı, hesap dönemi içerisinde varlıkların $0.95 \mathrm{kez}$ devrettiğini ifade etmektedir. Aktif devir hızının bileşenlerinden olan aktiflerin çoğu duran varlıklardan, duran varlıkların çoğu maddi duran varlıklardan oluşmaktadır. Varlıkların diğer bileşeni olan dönen varlıkların çoğu alacaklardan oluşmaktadır. 


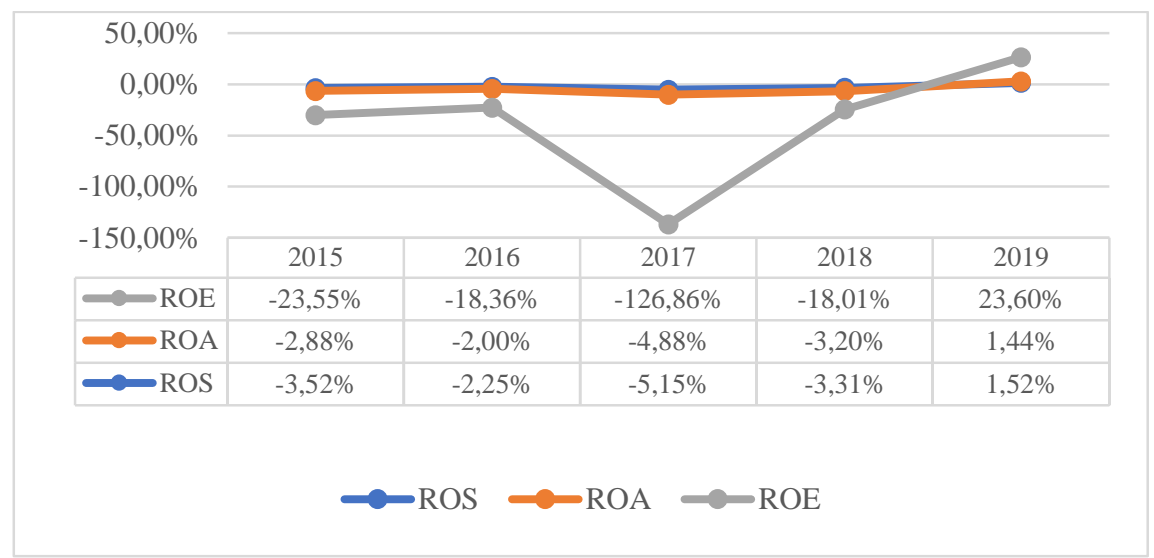

\section{Şekil 7. DuPont Karlılık Oranları Grafiği}

Şekil 7'de DuPont karlılık oranlarının yıllara göre değişim grafiği bulunmaktadır. Yıllar itibariyle dalgalanma göstermekte olan ROE, 2017 yılında en düşük değerinde iken 2019 yılı ROE'de görülen tek dönemdir. ROA yıllar itibariyle dalgalanma göstermekte ve aktiflerin kullanım verimliliği 2017 yılında en düşük değere sahipken, 2019 y1lında en yüksek değere sahiptir. Hastaneler grubunun sağlık hizmeti sunumuna ek tüm gelir ve gider faaliyetlerinin dikkate alındığı, net satışların karlılık yüzdesini ifade eden ROS da yıllara göre dalgalanma göstermekte olup en düşük karlılık oranı 2017 yılında, en yüksek karlılık oranı ise 2019 yılındadır. Genel olarak bakıldığında ise tüm DuPont karlılık oranlarının 2015-2018'de negatif olduğu, en düşük değerin 2017'de iken en yüksek değerin 2019'da görüldüğü saptanmıştır. Özellikle 2017 yılından 2019 yılına karlılık oranlarından önemli bir gelişim gözlemlenmiştir.

Tablo 2. Hastaneler Grubu ve Türkiye Özel Hastane İşletmeleri Karşılaştırmalı DuPont Analizi Bulguları

\begin{tabular}{|c|l|c|c|c|c|c|}
\hline \multicolumn{2}{|c|}{ Yıllar } & $\mathbf{2 0 1 5}$ & $\mathbf{2 0 1 6}$ & $\mathbf{2 0 1 7}$ & $\mathbf{2 0 1 8}$ & $\mathbf{2 0 1 9}$ \\
\hline \multirow{3}{*}{ ROE } & Hastaneler Grubu & $-23.55 \%$ & $-18.36 \%$ & $\begin{array}{c}- \\
126.86 \%\end{array}$ & $-18.01 \%$ & $\begin{array}{c}23.60 \\
\%\end{array}$ \\
\cline { 2 - 7 } & Türkiye Ortalamas1 & $1.20 \%$ & $-5.11 \%$ & $2.03 \%$ & $-5.93 \%$ & $2.41 \%$ \\
\cline { 2 - 7 } ROA & Hastaneler Grubu & $-2.88 \%$ & $-2.00 \%$ & $-4.88 \%$ & $-3.20 \%$ & $1.44 \%$ \\
\cline { 2 - 7 } & Türkiye Ortalamas1 & $0.37 \%$ & $-1.38 \%$ & $0.50 \%$ & $-1.52 \%$ & $0.70 \%$ \\
\hline \multirow{2}{*}{ ROS } & Hastaneler Grubu & $-3.52 \%$ & $-2.25 \%$ & $-5.15 \%$ & $-3.31 \%$ & $1.52 \%$ \\
\cline { 2 - 7 } & Türkiye Ortalamas1 & $0.49 \%$ & $-1.93 \%$ & $0.74 \%$ & $-2.16 \%$ & $0.85 \%$ \\
\hline
\end{tabular}

Tablo 2'de hastaneler grubunun DuPont analizi bulguları Türkiye Özel Hastane İşletmelerinin DuPont analizi bulguları ile karşılaştırılmıştır. Grubun ROE'si 2015-2018 yıllarında Türkiye ortalamasından düşük, 2019 yılında Türkiye ortalamasından yüksektir. Grubun ROA'sı 20152018 yıllarında Türkiye ortalamasından düşük, 2019 yılında ise Türkiye ortalamasından yüksektir. Gruba ait ROS, 2015-2018 yıllarında Türkiye ortalamasından düşük iken, 2019 yılında Türkiye ortalamasından yüksektir.

\section{SONUÇ}


Bu çalışmada bir hastaneler grubunun 2015-2019 yılları finansal performansı DuPont finansal analiz yöntemiyle değerlendirilmiştir. Hastaneler grubunun DuPont kârlılık oranlarının 20152018 yıllarında negatif, özsermayenin düşük, yabancı kaynak kullanımının yüksek, maliyet ve giderlerinin fazla, net kârın negatif olduğu ve zarar edildiği saptanmıştır. 2019 yılında ise DuPont kârlılık oranları pozitif değerde olmakla birlikte özsermayenin düşük, yabancı kaynak kullanımının yüksek, maliyet ve giderlerinin fazla olduğu tespit edilmiştir.

Karadeniz ve Koşan (2017), TCMB tarafindan yayımlanan hastane hizmetleri sektörünün DuPont finansal analiz yöntemiyle finansal performans değerlendirmesi çalışmalarında sektörün aktif ve özsermaye karlılıklarının 2012 ve 2014 yıllarında pozitif iken 2013 yılında negatif olduğunu saptanmışlardır. Sektörün yabancı kaynak kullanımlarının yüksek, bu nedenle aktif devir hızının düşük düzeyde ve dolayısıyla finansal riskin yüksek olduğu sonucuna varmışlardır. Çalışkan (2015), bir kamu hastanesinin DuPont analizi yöntemiyle finansal performans değerlendirmesi çalışmasında hastanenin 2010 ve 2013 yıllarında maliyetinin yüksek ve karının 0 olduğu; 2009, 2011 ve 2012 yıllarında karlılıklarının pozitif olduğunu saptamıştır. Literatürde yer alan araştırma bulguları bu araştırma kapsamındaki hastaneler grubunun bulgularını bazı yıllar kapsamında desteklemekte iken bazı y1llarda desteklememektedir. Bu durumun çalışmaların farklı evrenlerde ve farklı yıllarda yapılmasından kaynaklandığı düşünülmektedir.

Hastaneler grubunun DuPont karlılık oranları yıllar itibariyle dalgalanma göstermekte olup 2017 yılında en düşük değerlere sahip olmuş, 2017'den 2019'a ise olumlu gelişim yaşamıştır. Bu gelişime rağmen kaynaklar içinde özsermaye kullanımı düşüktür. Araştırma bulgularından hareketle hastaneler grubuna yabancı kaynak kullanımının azaltılması ve özsermaye kullanımının artırılması önerilmektedir. Özellikle 2015-2018 yıllarından karlılık oranlarının düşük olmasının temel nedeni maliyetler ve giderlerin net satışlardan yüksek olmasıdır. Karlılık saptanan 2019 yılında da maliyetler ve giderler ile net satışlar arasındaki fark düşük olup maliyet ve giderleri azaltıcı önlemler alınması önerilmektedir. Hastaneler grubunun DuPont karlılık oranları Türkiye ortalaması ile kıyaslandığında; oranların 2015-2018 yıllarında Türkiye ortalamasından düşük iken 2019 yılında ise yüksek olduğu saptanmıştır. Gelecek çalışmalarda farklı finansal analiz teknikleri ile finansal performansın ölçülmesi veya birden fazla finansal analiz tekniğinin bir arada kullanılarak finansal performans değerlendirmesi yapılması ve bu yöntemler arasındaki ilişkilerin incelenmesi önerilmektedir.

\section{KAYNAKÇA}

AĞIRBAŞ, İ. (2014). Sağlık Kurumlarında Finansal Yönetim ve Maliyet Analizi, Siyasal Kitabevi, Ankara.

AKGÜÇ, Ö. (2013). Finansal Yönetim, Avcıol Basım Yayın, İstanbul.

AKYÜZ, F., YEŞİL, T. ve KARA, E. (2019), "İşletmelerin DuPont Karlılık Analiziyle Performansının Belirlenmesi: Borsa İstanbul İmalat Sektörü Örneği”, Muhasebe ve Finansman Dergisi, 83: 61-84

AKYÜZ, K.C., YILDIRIM, İ. ve AKYÜZ, İ. (2020). "Birleşik Oran Analizi (Dupont) Yöntemi ile Kağıt ve Kağıt Ürünleri Sanayi Sektöründe Performans Ölçümü’. Bartın Orman Fakültesi Dergisi, 22(1): 164-169. 
ALMAZARI, A.A. (2012). "Financial Performance Analysis of the Jordanian Arab Bank by Using the DuPont System of Financial Analysis". International Journal of Economics and Finance, 4(4): 86-94.

ALPER, A. ve BIÇER, E.B. (2017). "Kamu Hastanelerinde Finansal Performansın Oran Analizi ile Ölçülmesi: Bir Kamu Hastanesi Örneğì”. Cumhuriyet Üniversitesi İktisadi ve İdari Bilimler Dergisi, 18(2): 337-357.

ARDIÇ, M. (2019). “Çay İşletmeleri Kurumunun (Çaykur) Finansal Performansının Dupont Finansal Analiz Sistemi Kullanılarak İncelenmesi”. Business \& Management Studies: An International Journal, 7(1): 352-372.

ARMUTLU, M.R ve GÜNGÖR, H.Y. (2019). “Turizm Sektöründe Özkaynak Kârlılığının Analizi”, Toplum Bilimleri Dergisi, 25: 137-152

AYANOĞLU, Y., ATAN, M. ve BEYLİK, U. (2010). "Hastanelerde Veri Zarflama Analizi (VZA) Yöntemiyle Finansal Performans Ölçümü ve Değerlendirilmesi”. Sağlıkta Performans ve Kalite Dergisi, 2(2): 40-62.

AYDEMİ, İ. (2018). "Hastanelerde Finansal Performansın Değerlendirilmesi: Türkiye Cumhuriyeti Merkez Bankası Hastane Hizmetleri Sektör Bilançolarında Bir Uygulama. Uluslararası Sağlık Yönetimi ve Stratejileri Araştırma Dergisi”, 4(2): 133-149.

AYDIN, N., BAŞAR, M. ve COŞKUN, M. (2010). Finansal Yönetim, Detay Yayınları, Ankara.

BAKIR, H. ve ŞAHIN, C. (2009). Yöneticiler İçin Finansal Tablolar Analizi, Detay Yayınları, Ankara.

BALCI, N. (2017). "Financial Performance Analysis with Topsis Technique: a Case Study of Public University Hospitals in Turkey". Yönetim ve Ekonomi Araştırmaları Dergisi, 15(1): 155-176.

BAŞTÜRK, F. H. (2004). "Dupont Kontrol Sisteminin (DKS) Sigorta Şirketlerinin Performans Ölçümüne Uyarlanması”. İktisat, İşletme ve Finans, 19(220): 100-114.

BRIGHAM, F. ve HOUSTON, J. F. (2014). Fundamentals of Financial Management (Finansal Yönetimin Temelleri), Çeviri Ed. Aypek, N., Nobel Yayıncılık, Ankara.

BÜLÜÇ, F., ÖZKAN, O. ve AĞIRBAŞ, İ. (2017). "Üniversite Hastanelerinin Finansal Performansının Oran Analizi Yöntemiyle Değerlendirilmesi”. Business \& Management Studies: An International Journal, 5(2): 268-281.

BÜYÜKARIKAN, U., ERYILMAZ, C. (2020). “Tarım Sektöründeki İşletmelerin Finansal Performansının DuPont Modeliyle Analizi”. Erzincan Üniversitesi Sosyal Bilimler Enstitüsü Dergisi, 13(2): 129-141.

CHANG, K.J., CHICHERNEA, D. C. ve HASSABELNABY, H. R. (2014). “On the DuPont Analysis in the Health Care Industry”. Journal of Accounting and Public Policy, 33(1): 83-103. 
CHANG, K.J., CHICHERNEA, D.C., HASSABELNABY, H.R. (2011). "Can DuPont Analysis Be Used in Assessment of Profitability Performance in the Health Care Industry?", https://ssrn.com/abstract=1911626, 16.03.2021.

CREIXANS-TENAS, J. ve ARIMANY-SERRAT, N. (2018). "Influential Variables On The Profitability Of Hospital Companies”. Intangible Capital, 14(1): 171-185.

ÇALIŞKAN, S. (2015). "Kamu Hastanelerinde Dupont Analizi ile Finansal Performans Değerlendirilmesi ve Bir Uygulama”, Yüksek Lisans Tezi, Eskişehir Osman Gazi Üniversitesi, Sosyal Bilimler Enstitüsü, Eskişehir.

DONKLE, R. ve GULLICKSON, D. (2003). The Financial Effects of Critical Access Hospital Conversion.

ERDURU, İ. (2018). Türkiye'de İlaç Sektörü Alanında Faaliyet Gösteren İşletmelerin Aktif ve Özsermaye Karlılıklarının Dupont Analizi Yöntemi ile Değerlendirilmesi. Uysal Şahin, Ö. Köleoğlu, N (Ed.) Teoride ve Uygulamada Sağlık Ekonomisi ve Politikaları Güncel Sorunlar ve Araştırmalar içinde (303-326). Rating Academy Yayınları, Ankara.

GAPENSKI, L.C. (2008). Healthcare Finance: An Introduction to Accounting and Financial Management, 4th edition, Health Administration Press, Chicago, USA.

GITMAN, J.L. (2002). Principles of Managerial Finance, Pearson, USA.

GRUEN, R. ve HOWARTH, A. (2005). Financial Management in Health Services, Open University Press, Berkshire, England.

GÜMÜŞ, U. ve ÇIBIK, E. (2018). “Borsa'da İşlem Gören Gayrimenkul Yatırım Ortaklığı İşletmelerinin Birleşik Oran Analizi (Dupont) Yöntemiyle Performansının Ölçülmesi”. Hitit Üniversitesi Sosyal Bilimler Enstitüsü Dergisi, 11(3): 2178-2194.

HAO, Y., CHOI, S.U. (2019). “Operating performance of Chinese online shopping companies: An analysis using DuPont components”. Sustainability, 11(13): 1-13.

KARADENIZ, E. ve KOŞAN, L. (2017). "Hastane Hizmetleri Sektörünün Aktif ve Özsermaye Karlılık Performansının Analizi: Hastane Hizmetleri Sektör Bilançolarında Bir Araştırma". İşletme ve İktisat Çalışmaları Dergisi, 5(1): 37-47.

KARADENIZ, E., KOŞAN, L., GÜNAY, F. ve DALAK, S. (2019). “Otel İşletmelerinde Kârlılı̆̆1 Etkileyen Değişkenlerin DuPont Analiz Tekniğiyle Ölçülmesi: Avrupa Borsalarında Ekonometrik Bir Analiz”, Muhasebe ve Finansman Dergisi, 81: 21-36

LADVENICOVÁ, J., BAJUSOVÁ, Z., GURČIK, L ve ČERVENÝ, D. (2019). "Dupont Analysis of Farms in V4 Countries", Visegrad Journal on Bioeconomy and Sustainable Development, 8(2): 82-86

LOUKOPOULOS, G. ve ROUPAS, T. (2014). "Financial Analysis of the Greek Private Health Sector Over the Last Decade (2002-2012)”. European Research Studies, 17(2): 3-19.

MALI, D.B. (2020). "A Comparative Study on Financial Performance of Cadila Healthcare Limited and Torrent Pharmaceuticals Limied in Gujarat". Online Journal of Multidiseiplinary Subjects, 12(1): 343-350. 
MORTAŞ, M. (2020). Enerji Sektöründe Faaliyet Gösteren İşletmelerin Karlılıklarının Dupont Analizi ile İncelenmesi: Bıst Elektrik (Xelkt) Endeksinde Bir Araştırma, Hasan Babacan (Ed.) Sosyal, Beşeri ve İdari Bilimler Alanında Akademik Çalışmalar-1 içinde (301319). Gece Kitaplı̆̆ Kitabevi, Ankara

NOH, J.W., LEE, H., CHA, S. ve LEE, Y. (2018). “Assessment of Korean Hospitals Management Using Dupont Analysis". Korea Journal Of Hospital Management, 23(4): 53-64.

NURUL, K. B., SHAH A. ve MONZUR, H. (2018). "Dupont Analysis of Return on Common Stock Holder's equity in Pharmaceutical Industry of Bangladesh”. Global Journal of Management and Business, 18(1): 9-15.

OKKA, O. (2015). Finansal Yönetim Teori ve Çözümlü Problemler, Nobel Yayıncılık, Ankara.

ÖZBAY, D. ve TAŞEL, F. (2020). “İşletmeler İçin Uluslararasılaşmanın Önemi ve Finansal Performansa Olan Etkisine Yönelik Bir Araştırma”.

Alanya Akademik Bakış Dergisi, 4(3): 789-805.

ÖZGÜlBAŞ, N., KOYUNCUGIIL, A.S., DUMAN, R. ve HATİPOĞLU, B. (2008). “Özel Hastane Sektörünün Finansal Değerlendirmesi”. Muhasebe ve Finansman Dergisi, (40): $120-131$.

POYRAZ, E. (2008). Açıklamalı Örneklerle Finansal Yönetim, Ekin Yayınevi, Bursa.

PRAJAPATI, S. ve DANTA S. (2015). "Use of Dupont Five Point Analysis to Study CNX Pharma Index". International Journal of Current Engineering and Technology, 5(5): 3398-3406.

SHAHNIA, C., ENDRI, E. (2020). "Dupont Analysis for the financial performance of trading, service \& investment companies in Indonesia". International Journal of Innovative Science and Research Technology, 5(4): 193-211.

SHEELA, S.C. ve KARTHIKEYAN, K. (2012). "Financial Performance Of Pharmaceutical Industry In India Using Dupont Analysis". European Journal of Business and Management, 4(14): 84-91.

TURGUT, M., IŞIKÇELIK, F. ve AĞIRBAŞ, İ. (2019). Sağlık Kurumlarında Maliyet Analizi ve Finansal Analiz, İsmail Ağırbaş (Ed.) Să̆lık Ekonomisi ve Să̆lık Kurumları Yönetiminde Temel Konular içinde (135-169). Siyasal Kitabevi, Ankara.

TURNER, J., BROOM, K., ELLIOTT M. ve LEE J.F. (2015). “A Decomposition of Hospital Profitability: an Application of Dupont Analysis to the US Market". Health Services Research and Managerial Epidemiology, 1-10. 